\title{
PENGARUH KOMPETENSI APARATUR DESA, SISTEM PENGENDALIAN INTERNAL DAN KOMITMEN ORGANISASI TERHADAP AKUNTABILITAS PENGELOLAAN DANA DESA DI KECAMATAN MUARA ENIM KABUPATEN MUARA ENIM
}

\author{
, Zulkifli ${ }^{1}$, Sandrayati ${ }^{2}$. Neni Ariani ${ }^{3}$ \\ ${ }^{3}$ Jurusan Akuntansi, Politeknik Negeri Sriwijaya, Jl. Srijaya Negara, Palembang \\ e-mail: zulkifliwancik@gmail.com
}

\begin{abstract}
Abstrak
Tujuan penelitian ini adalah untuk mengetahui pengaruh kompetensi aparatur desa, sistem pengendalian internal, dan komitmen organisasi terhadap akuntabilitas pengelolaan dana desa di Kecamatan Muara Enim Kecamatan Muara Enim. Populasi dalam penelitian ini adalah aparatur desa pada sepuluh desa di Kecamatan Muara Enim yaitu 70 orang.Dengan teknik purposive sampling, sampel penelitian ini sebanyak 40 responden.Data dikumpulkan dengan menyebarkan secara langsung kuesioner kepada responden.Teknik analisis data yang digunakan adalah regresi linear berganda dengan software SPSS versi 25. Hasil penelitian menunjukkan kompetensi aparatur desa, sistem pengendalian internal dan komitmen organisasi secara bersama-bersama berpengaruh positif dan signifikan terhadap efektivitas pengelolaan dana desa di Kecamatan Muara Enim Kabupaten Muara Enim. Secara parsial, Kompetensi aparatur desa berpengaruh positif dan signifikan terhadap akuntabilitas pengelolaan dana desa. Sistem pengendalian berpengaruh positif dan signifikan terhadap akuntabilitas pengelolaan dana desa. Komitmen organisasi berpengaruh positif dan signifikan terhadap akuntabilitas pengelolaan dana desa.
\end{abstract}

\begin{abstract}
The purpose of this research is to determine the influence of village apparatus competency, internal control system, and organizational commitment to accountability of village fund management in Muara Enim Subdistrict, Muara Enim Subdistrict. The population in this study is village apparatus in ten villages in Muara Enim Subdistrict which is 70 people. With purposive sampling techniques, this study sampled as many as 40 respondents. The data is collected by distributing questionnaires directly to respondents. The data analysis technique used is multiple linear regression with SPSS version 25 software. The results showed the competence of village apparatus, internal control system and organizational commitment together have a positive and significant effect on the effectiveness of village fund management in Muara Enim Subdistrict, Muara Enim Regency. In part, the competence of village apparatus has a positive and significant effect on the accountability of village fund management. The control system has a positive and significant effect on the accountability of village fund management. The organization's commitment has a positive and significant impact on the accountability of village fund management.
\end{abstract}

Keywords: Competency of Village Apparatus, Internal Control System, Organizational Commitment, Accountability of Village Fund Management.

Kata kunci: Kompetensi Aparatur Desa, Sistem Pengendalian Internal, Komitmen Organisasi, Akuntabilitas

Pengelolaan Dana Desa.

\section{PENDAHULUAN}

Semenjak terpilihnya bapak Joko Widodo sebagai Presiden Indonesia tentumembawa banyak perubahan pada tatanan kehidupan bangsa, baik dari segi pemerintah maupun tatanan lainnya. Salah satu bentuk perubahan yang dilakukan oleh bapak Joko Widodo adalah mengusung sebuah program yang disebut Nawa Cita yaitu program membangun Negara Indonesia dari pinggiran 
dengan cara memperkuat daerah dan desa dengan pemberiaan dana. Hal ini diperkuat dengan keluarnya UU No.6 Tahun 2014 yang mengatur tentang Desa dan Dana Desa.Tentu hal ini memperjelas komitmen Pemerintah Pusat dan Presiden untuk membangun ketertinggalan desa sehingga diharapkan terciptanya pemerataan di Negara Indonesia. Dana yang diberikan oleh pemerintah pusat kepada desa lebih dikenal dengan sebutan dana desa. Dana desa yang diberikan ini bertujuan sebagai wujud pemerataan dari pemerintah untuk membangun desa yang mandiri dan madani sehingga bisa menjadi penopang negara Indonesia kedepannya.

Hal ini tentunya harus berdampak positive bagi kemajuan desa itu sendiri, pemerintah telah memberikan kepercayaan penuh terhadap desa dengan memberikan alokasi berupa dana desa untuk mendukung sistem penyelenggaran yang ada di desa. Hal ini diharapkan agar desa bisa mampu membangun desanya sendiri dengan mandiri sehingga bisa menciptakan landasan yang kuat untuk membangun desa yang mandiri dan sejahterah dan mencapai kesejahteraan untuk setiap masyarakat desa.Dana desa ini pertama kali di laksanakan di Indonesia dimulai pada tahun 2015. Pemberian dana desa ini dilakukan secara berkala oleh pemerintah pusat Pemberian dana desa ini bersumber langsung dari Anggaran Pendapatan dan Belanja Negara (APBN).

Pemberian dana desa ini pun tak sedikit dilakukan oleh pemerintah, dimulai pada awal pemberian dana desa pada tahun 2015 pemerintah mencanangkan dana desa sebesar Rp20.700.000.000.000 dimana setiap desa akan menerima dana sebesar Rp280.000.000, lalu pada tahun 2016 pemerintah menambah besar canangan untuk dana desa yaitu sebesar Rp46.980.000.000.000 dimana setiap desa akan menerima alokasi dana sebesar Rp628.000.000. Kemudian berlanjut pada tahun 2017 dan 2018 dana desa yang di canangkan sama yaitu berjumlah Rp60.000.000.000.000 dimana setiap desa akan menerima rata-rata alokasi dana sebesar Rp804.000.000. dan pada tahun 2019 anggaran dana desa juga mengalami peningkatan dimana jumlah yang dianggarkan oleh pemerintah berjumlah Rp70.000.000.000.000 dimana setiap desa akan menerima rata-rata alokasi dana sebesar Rp933.000.0000. (www.djpk.kemenkeu.go.id).

Pemberian dana desa yang tidak sedikit ini diharapkan mampu memberikan harapan baru bagi setiap masyarakat yang tinggal di desa. Masyarakat desa melalui pemerintah desa diharapkan bisa membangun setiap sendi kehidupan yang ada di desa. Kucuran dana yang besar dari pemerintah tentunya bisa membangun ketertinggalan desa dengan kota. Sehingga tujuan utama dari Pancasila bisa terwujud yaitu kemanusiaan yang adil dan beradab serta keadilan sosial bagi seluruh rakyat Indonesia. Setiap jumlah dana desa yang diberikan oleh pemerintah kepada desa memiliki jumlah yang tidak sama, hal ini dipengaruhi oleh banyak faktor antara lain jumlah penduduk desa, luas wilayah, angka kemiskinan dan tingkat geologis .

Namun pada pelaksanaanya dilapangan hal ini justru berbanding terbalik dengan apa yang diharapkan. Penggunaan dana desa yang diharapkan mampu membangun ekonomi desa serta pembangunan desa dan meningkatkan kesejahteraan masyarakat justru malah digunakan untuk kepentingan pribadi kepala desa dengan tujuan memperkaya diri dan sebagainya. Menurut sumber yang dilansir 5 Maret 2021 dari (Sumateranews.co.id) menyebutkan bahwa telah terjadi peyelewengan penggunaan dana desa Tahun Anggaran 2016,2017,2018 di Wilayah Kabupaten Muara Enim yang merugikan negara hingga miliaran rupiah, yang dilakukan oleh oknum kepala desa berinisial Alf Kepala desa Muara Dua Kecamatan Semendo Darat Laut dan oknum lainnya berinisial EC Oknum Kades Rekimay Kecamatan Semendo Darat Tengah diduga.

Kepala desa tersebut dilaporkan oleh Ketua LAI BPAN DPD Sumsel Bpk.Syamsudin Djoesman kepada Kejaksaan Negeri Muara Enim, menurut masyarakat Oknum kades dan jajaranya tidak transparan dalam mensosialisasikan dana desa dan untuk memuluskan aksinya Laporan Pertangggung Jawaban (LPJ) diduga sengaja dibuat fiktif. Tentu hal ini bisa terjadi sebagai wujud tidak jalannya fungsi pengelolaan dana desa yang baik berdasarkan peraturan pemerintah yang telah ditetapkan. Dana desa yang awalnya digunakan untuk pembangunan desa dan kesejahteraan masyarakat malah disalahgunakan untuk kepentingan oknum pribadi kepala desa yang justru mencoreng nama baik kepala desa itu sendiri. Kepala desa yang tadinya sebagai perpanjangan tangan rakyat untuk pengelolaan dana desa ini malah disalah gunakan untuk kepentingan pribadinya sendiri. 
Dalam peraturan menteri dalam negeri (Permendagri) No. 20 Tahun 2018 tentang pengelolaan keuangan desa pasal 2 ayat 1 dinyatakan bahwa keuangan desa dikelola berdasarkan asas transparan, akuntatabel, partisipatif serta dilakukan dengan tertib dan disiplin anggaran. Asas - asas yang tercantum dalam permendagri No.20 Tahun 2018 ini diharapkan bisa dilaksanakan dengan baik oleh setiap aparatur desa sehingga pengelolaan dana desa yang baik bisa terwujud sehingga efisiensi dan efektivitas penggunaan dana desa dirasakan oleh setiap masyarakat.

Dalam mencapai pengelolaan keuangan desa yang akuntabilitas tentu saja harus didukung dengan kompetensi aparatur yang baik pula. Kompetensi aparatur desa yang baik merupakan bagian yang penting dalam proses pengelolaan dana desa dan kegiatan pemerintah lainnya dimana setiap aparatur desa memiliki komitmen yang tinggi untuk melaksanakan pengelolaan dengan sebaik-baiknya, dan bertanggung jawab Permendagri No. 20 Tahun 2018 menyatakan, bahwa pengelolaan keuangan desa meliputi ;

1. Perencanaan

2. Pelaksanaan

3. Penatausahaan

4. Pelaporan dan pertanggungjawaban

\section{Kompetensi Aparatur Desa}

Menurut Peraturan Menteri Dalam Negeri Republik Indonesia Nomor 108 Tahun 2017 Tentang Kompetensi Pemerintahan, Kompetensi adalah kemampuan dan karakteristik yang dimiliki oleh seorang pegawai Aparatur Sipil Negara, berupa pengetahuan, keterampilan, dan sikap perilaku yang diperlukan dalam pelaksanaan tugas jabatannya sehingga dapat melaksanakan tugasnya secara profesional, efektif dan efisien.

\section{Sistem Pengendalian Internal Pemerintah} Menurut Mulyadi (2017:129) Sistem Pengendalian Internal merupakan struktur organisasi, metode dan ukuran-ukuran yang dikoordinasikan untuk menjaga asset organisasi, mengecek ketelitian dan keandalan data akuntansi, mendorong efisiensi dan mendorong dipatuhinya kebijakan. Sistem Pengendalian Internal merupakan salah satu cara untuk meminimalisir terjadinya asimetri informasi yaitu dengan cara monitoring cost. Pemerintah pusat maupun pemerintah daerah berkewajiban untuk penuh akan pelaksanaan tugas-tugas dalam pemerintah desa.

\section{METODOLOGI PENELITIAN Pemerintah Desa}

Menurut permendagri No. 20 Tahun 2018, "Pemerintah Desa adalah kepala Desa atau yang disebut dengan nama lain dibantu perangkat Desa sebagai unsur penyelenggara Pemerintahan Desa".

\section{Akuntabilitas Pengelolaan Dana Desa \\ Menurut Peraturan Pemerintah No.71 \\ Tahun 2010 tentang Standar Akuntansi Pemerintah "Akuntabilitas adalah mempertanggungjawabkan pengelolaan sumber daya serta pelaksanaan kebijakan yang dipercayakan kepada entitas pelaporan dalam mencapai tujuan yang telah ditetapkan secara periodik.}

mengembangkan dan memanfaatkan Sistem Pengendalian Internal.

Berdasarkan PP No. 60 Tahun 2008, unsur SPIP terdiri atas:
1. Lingkungan pengendalian
2. Penilaian risiko
3. Kegiatan pengendalian
4. Informasi dan komunikasi
5. pemantauan

\section{Komitmen Organisasi}

Menurut Porter dan Minner dalam Kusumaputri (2015) “ komitmen organisasi adalah suatu keadaan dimana seorang karyawan tetap bertahan pada organisasi serta adanya sikap kesedian untuk berusaha lebih pada organiasasi tersebut".

Tiga dimensi komitmen organisasional menurut Robbins dan Judge (2015) adalah:

1. komitmen afektif

2. komitmen berkelanjutan

3. komitmen normatif

\section{KERANGKA PEMIKIRAN}

Berdasarkan perumusan masalah, teori terkait dan beberapa hasil penelitian sebelumnya, maka kerangka pemikiran atau paradigma penelitian dari penelitian ini dapat divisualisasikan dalam bentuk skematis berikut: 
2019:136).Dalam penelitian ini, populasi yang diambil adalah perangkat desa pada 10 desa di

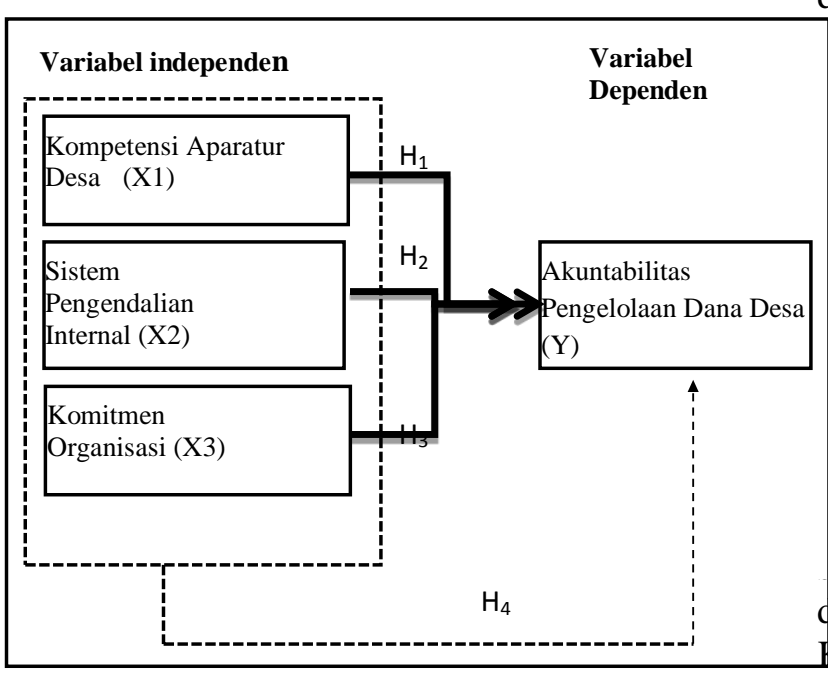

Sesuai dengan gambar di atas, dapat dideskripsikan bahwa Kompetensi Apatur Desa $\left(X_{1}\right)$, Sistem Pengendalian Internal $\left(X_{2}\right)$, dan Komitmen Organisasi $\left(\mathrm{X}_{3}\right)$ berpengaruh terhadap variabel dependen yaituAkuntabilitas Pengelolaan Dana Desa (Y).

\section{METODE PENELITIAN Populasi dan Sampel}

Populasi adalah wilayah generalisasi yang terdiri atas: objek/subjek yang mempunyai kuantitas dan karakteristik tertentu yang diterapkan oleh peneliti untuk mempelajari dan kemudian ditarik kesimpulannya(Sugiyono,

Dalam penelitian ini peneliti menggunakan teknik pengumpulan data berupa kuisioner. Peneliti akan menyebarkan kuisioner kepada perangkat desa yang ada di KecamatanMuara Enim Kabupaten Muara Enim yang memenuhi kriteria dalam populasi yang ada.

\section{Pengujian Data}

Pengujian data yang dimanfaatkan dalam penelitian ini adalah uji validitas, uji reliabilitas, uji asumsi klasik, normalitas, uji multikolinearitas, uji heterokedastisitas, uji analisis regresi linear berganda, dan uji hipotesis yaitu koefisien determinasi $\left(\mathrm{R}^{2}\right)$, uji $\mathrm{T}$ (Uji Parsial), uji F (Uji Simultan).

\section{Analisis Regresi Linear Berganda}

Analisis yang digunakan adalah Analisis regresi linier berganda untuk mengetahui pengaruh atau hubungan secara linier antara dua atau lebih variabel independen dengan satu variabel dependen dengan tujuan untuk memprediksi rata-rata populasi atau nilai rata-rata variabel dependen berdasarkan nilai variabel independen yang diketahui.
Recamatan Muara Enim Kabupaten Muara Enim.

Sampel adalah bagian dari jumlah dan arakteristik yang dimiliki populasi (Sugiyono, 019).Sementara, sampel yang dipakai dalam enelitian ini memakai teknik Purposive ampling. Menurut Sugiyono (2019:119), Purposive sampling adalah teknik penentuan ampel dengan pertimbangan tertentu." Sampel ari penelitian ini adalah karena itu, sampel yang lipilih sengaja ditentukan berdasarkan kriteria ertentu. Kriteria sampel pada penelitian ini dalah "Pemerintah desadi bidang keuangan ehubungan dengan pengelolaan keuangan dana desa di Kecataman Muara Enim"terdiri atas Kepala Desa, Sekretaris Desa, Bendahara Desa dan Kepala Urusan Pemerintah di 10 Desa Di Kecamatan Muara Enim.

Penentuan kriteria sampel didasari bahwa Kepala Desa, Sekretaris Desa, Bendahara dan Kepala Urusan Pemerintah terlibat langsung dalam perencanaan, pelaksanaan, penataushaan, pelaporan dan pertanggungjawaban pengelolaan dana desa. Dengan demikian jumlah sampel penelitian berjumlah 40 orang.

Dengan demikian, regresi linear berganda dinyatakan dalam persamaan matematika sebagai berikut:

$$
\mathbf{Y}=\mathbf{a}+\mathbf{b}_{1} \mathbf{X}_{1}+\mathbf{b}_{2} \mathbf{X}_{2}+\mathbf{b}_{3} \mathbf{X}_{3}+\mathbf{e}
$$

Dimana:

Y : Akuntabilitas Pengelolaan Dana Desa

$\mathrm{X}_{1} \quad$ : Kompetensi Aparatur Desa

$\mathrm{X}_{2} \quad$ : Sistem Pengendalian Internal

$\mathrm{X}_{3} \quad$ : Komitmen Organisasi

a : konstanta

$\mathrm{b}_{1}, \mathrm{~b}_{2}, \mathrm{~b}_{3}$ : koefisien regresi

e : error term

\section{HASIL DAN PEMBAHASAN}

Pengambilan data dalam skripsi ini diperoleh dengan mengantarkan langsung kuesioner ke pihak-pihak yang terlibat langsung 
dalam perencanaan, pelaksanaan, penataushaan, pelaporan dan pertanggungjawaban pengelolaan dana desa.Pihak-pihak tersebut antara lain Kepala Desa, Sekretaris Desa, Bendahara Desa, dan Kepala Urusan Pemerintah sebagai responden yang dipilih peneliti.Pengisian kuesioner ini ditujukan ke 10 Desa, dan setiap Desa dibagikan sebanyak 4 (empat) kuesioner yang penulis bagikan untuk masing-masing Desa yang menjadi sampel dalam penelitian ini.Jumlah sampel dalam penelitian ini sebanyak 40
responden.Pengembalian kuesioner yang diterima penulis sebanyak 40 kuesioner dan seluruhnya dapat diolah karena semua kuesioner yang penulis bagikan telah diisi secara lengkap oleh responden.

Data primer tersebut diolah dengan menggunakan software SPSS versi 25 untuk mengetahui uji validitas, uji reliabilitas, uji asumsi klasik, normalitas, uji multikolinearitas, uji heterokedastisitas, analisis regresi linear berganda, koefisiendeterminasi, uji T, uji F.

\section{Uji Normalitas}

Uji normalitas bertujuan untuk melihat apakah variabel independen dan variabel dependen berdistribusi normal atau tidak.

Tabel 1Hasil Uji Normalitas Data

One-Sample Kolmogorov-Smirnov Test

\begin{tabular}{llr} 
& & \multicolumn{2}{c}{$\begin{array}{c}\text { Unstandardized } \\
\text { Residual }\end{array}$} \\
\hline $\mathrm{N}$ & & 40 \\
\hline Normal Parameters & & Mean \\
\cline { 2 - 3 } & Std. Deviation & .0000000 \\
\hline Most Extreme Differences & Absolute & .84351179 \\
\cline { 2 - 3 } & Positive & .086 \\
\cline { 2 - 3 } & Negative & .064 \\
\hline Test Statistic & & -.086 \\
\hline Asymp. Sig. (2-tailed) & & .086 \\
\hline
\end{tabular}
a. Test distribution is Normal.
b. Calculated from data.
c. Lilliefors Significance Correction.
d. This is a lower bound of the true significance.

Sumber: Data yang diolah, 2021

Berdasarkan tabel 4.7 di atas tersebut dapat dilihat bahwa nilai signifikansi Residual (Asymp. Sig. 2-tailed) yang diperoleh dari hasil perhitungan Kolmogorov-Smirnov adalah 0,200 yang berarti signifikansi > $0,05(0,200>0,05)$, Maka dapat disimpulkan bahwa nilai residual yang dihasilkan berdistribusi normal dan data yang tersedia dapat digunakan dalam statistik.

\section{Uji Multikolinearitas}

Uji multikolonieritas bertujuan Untuk mendeteksi ada tidaknya gejala multikolinearitas didalam model regresi, dapat dilihat dari nilai Tolerance dan Variance Inflation Factor (VIF). Jadi nilai tolerance yang tinggi sama dengan nilai VIF tinggi (karena $\mathrm{VIF}=1 /$ Tolerance) . 


\begin{tabular}{|c|c|c|c|c|c|c|c|c|}
\hline \multicolumn{9}{|c|}{ Coefficients $^{a}$} \\
\hline \multirow{2}{*}{\multicolumn{2}{|c|}{ Model }} & \multicolumn{2}{|c|}{$\begin{array}{l}\text { Unstandardized } \\
\text { Coefficients }\end{array}$} & \multirow{3}{*}{$\begin{array}{l}\text { Standar } \\
\text { dized } \\
\text { Coeffici } \\
\text { ents } \\
\text { Beta } \\
\end{array}$} & \multirow[b]{2}{*}{$\mathrm{T}$} & \multirow[b]{2}{*}{ Sig. } & \multicolumn{2}{|c|}{ Collinearity Statistics } \\
\hline & & $\mathrm{B}$ & Std. Error & & & & Tolerance & VIF \\
\hline \multirow[t]{3}{*}{1} & (Constant) & $-33,183$ & 7,450 & & -4.454 &, 000 & & \\
\hline & Kompetensi & ,182 & ,084 & ,162 & 2,154 & ,038 & ,956 & 1,046 \\
\hline & Spip & ,212 & ,023 & ,706 & 9,272 & ,000 & ,930 & 1,075 \\
\hline & Komitmen & 1.169 & .250 & .363 & 4.674 & .000 & .895 & 1.118 \\
\hline
\end{tabular}

Sumber: Data yang diolah, 2021.

Berdasarkan tabel tersebut dapat dilihat bahwa nilai toleransi variabel Kompetensi Aparatur Desa $\left(\mathrm{X}_{1}\right)$ sebesar 0,956, variabel Sistem Pengendalian Internal $\left(\mathrm{X}_{2}\right)$ sebesar 0,930 dan variabel Komitmen Organisasi $\left(\mathrm{X}_{3}\right)$ sebesar 0,895, Ketiga variabel ini menghasilkan nilai tolerance yang lebih besar dari 0,10. Untuk nilai VIF pada variabel Kompetensi Aparatur Desa $\left(X_{1}\right)$ sebesar 1,046, variabel Sistem Pengendalian Internal $\left(\mathrm{X}_{2}\right)$ sebesar 1,075, dan variabel Komitmen Organisasi $\left(\mathrm{X}_{3}\right)$ sebesar 1,118,. Ketiga variabel ini juga menghasilkan nilai VIF yang kurang dari 10. Maka dapat disimpulkan bahwa tidak terjadinya gejala multikolinearitas pada model regresi dalam penelitian

\section{Uji Heterokedastisitas}

Uji heteroskedastisitas digunakan untuk menguji apakah dalam model regresi terjadi ketidaksamaan varian dari residual satu pengamatan ke pengamatan yang lain.

Tabel 3Hasil Uji Heterokedastisitas

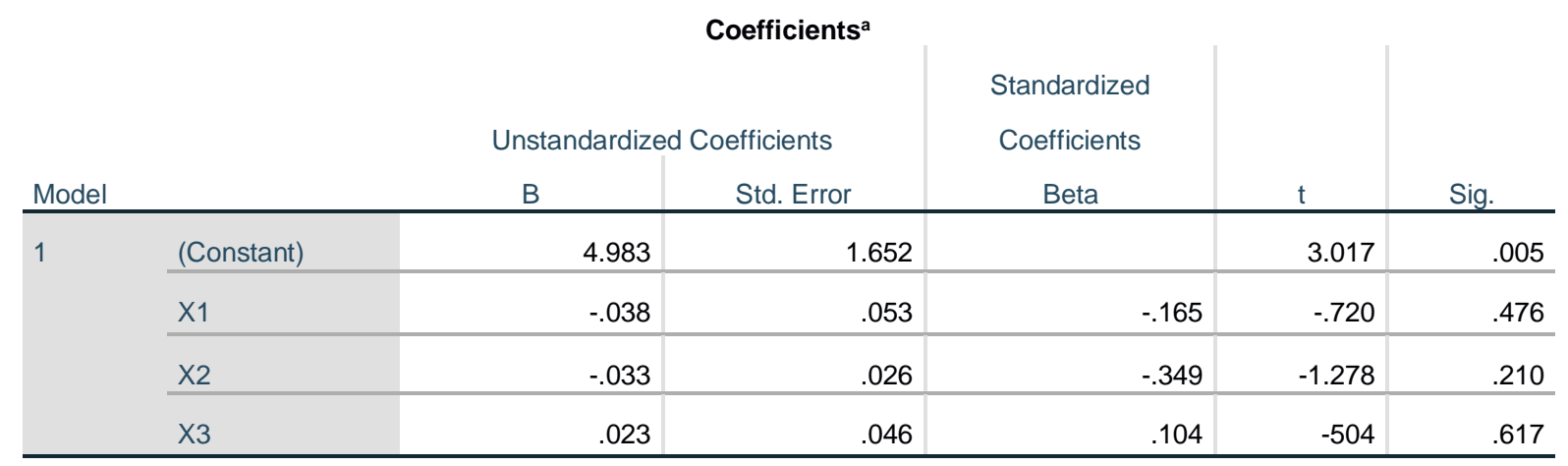

a. Dependent Variable: RES2

Sumber: Data yang diolah, 2021.

Dari tabel tersebut menunjukkan bahwa nilai signifikansi variabel Komitmen Organisasi sebesar 0,476, variabel Sistem Pengendalian Internal sebesar 0,210, Komitmen Organisasi sebesar 0,617 Maka dapat disimpulkan bahwa model regresi dalam penelitian ini tidak terjadi adanya gejala heteroskedastisitas.

Selain itu, ada juga metode lain untuk melihat ada atau tidaknya gejala Heteroskedastisitas yaitu dengan metode Scatterplots Regresi sebagai berikut: 


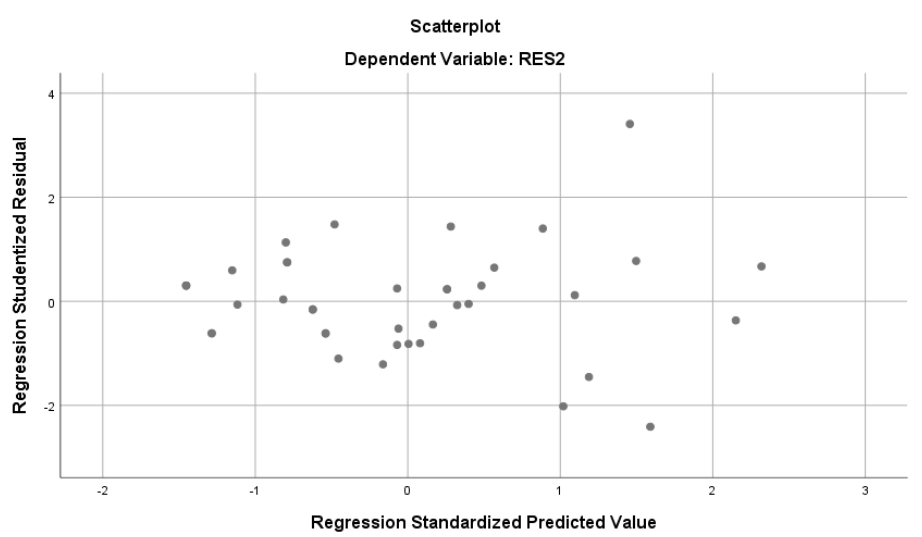

Sumber: Data yang diolah, 2021.

Gambar 1Hasil Uji Heteroskedastisitas dengan metode Scatterplots Regresi

Berdasarkan gambar di atas menunjukkan bahwa titik-titik menyebar secara acak dan tidak membentuk pola tertentu seperti gelombang dan garis lurus. Dengan demikian, dapat disimpulkan bahwa tidak terjadi gejala heteroskedastisitas.

\section{Hasil Analisis Regresi Linier Berganda}

Analisis regresi linier berganda digunakan untuk mengukur besarnya pengaruh antara dua atau lebih variabel independen dengan satu variabel independen. Metode ini digunakan untuk menguji hipotesis dan melihat kekuatan hubungan antara Kompetensi Aparatur Desa, Sistem Pengendalian Internal, dan Komitmen Organisasi Terhadap Akuntabilitas Pengelolaan Dana Desa.

Tabel 4 Hasil Analisis Regresi Linier Berganda

\begin{tabular}{|c|c|c|c|c|c|c|}
\hline & & & oefficients ${ }^{a}$ & & & \\
\hline & & Unstandardize & efficients & $\begin{array}{l}\text { Standardized } \\
\text { Coefficients }\end{array}$ & & \\
\hline & & $\mathrm{B}$ & Std. Error & Beta & $\mathrm{t}$ & Sig. \\
\hline 1 & (Constant) & -33.183 & 7.450 & & -4.454 & .000 \\
\hline & X1 (Kompetensi) & .182 & .084 & .162 & 2.154 & .038 \\
\hline & X2 (SPIP) & .212 & .023 & .706 & 9.272 & .000 \\
\hline & X3 (Komitmen) & 1.169 & .250 & .363 & 4.674 & .000 \\
\hline
\end{tabular}

a. Dependent Variable: $Y$

Sumber: Data yang diolah, 2021.

Berdasarkan tabel 4.16 hasil analisis linier berganda tersebut tercantum nilai konstanta dan nilai-nilai koefisien regresi linier berganda untuk masing-masing variabel bebas. Berdasarkan nilai-nilai tersebut maka dapat ditentukan model regresi linier berganda yang dinyatakan dalam bentuk persamaan sebagai berikut

$$
\mathbf{Y}=\mathbf{a}+\mathbf{b}_{1} \mathbf{X}_{1}+\mathbf{b}_{2} \mathbf{X}_{2}+\mathbf{b}_{3} \mathbf{X}_{3}+\mathbf{e}
$$

$Y=-33,183+0,162 X_{1}+0,706 X_{2}+0,363 X_{3}+\varepsilon$
Keterangan :

Y : Akuntabilitas Pengelolaan Dana Desa

$\mathrm{X}_{1} \quad$ : Kompetensi Aparatur Desa

$\mathrm{X}_{2} \quad$ : Sistem Pengendalian Internal

$\mathrm{X}_{3} \quad$ : Komitmen Organisasi

a : konstanta

$\mathrm{b}_{1}, \mathrm{~b}_{2}, \mathrm{~b}_{3} \quad$ : koefisien regresi

e : errorterm

Hasil Uji Hipotesis

Uji Koefisien Determinasi $\left(\mathbf{R}^{\mathbf{2}}\right)$

Koefisien determinasi $\left(\mathrm{R}^{2}\right)$ untuk melihat sejauh mana kontribusi kompetensi aparatur desa, sistem 
pengendalian internal dan komitmen organisasi terhadap akuntabilitas pengelolaan dana desa.

Tabel 5Hasil Uji Koefisien Determinasi $\left(\mathrm{R}^{2}\right)$

\section{Model Summary}

\begin{tabular}{|c|c|c|c|c|}
\hline \multirow[b]{2}{*}{ Model } & \multicolumn{3}{|c|}{ ( } & \multirow[b]{2}{*}{$\begin{array}{l}\text { Std. Error of } \\
\text { the Estimate }\end{array}$} \\
\hline & $\mathrm{R}$ & R Square & $\begin{array}{c}\text { Adjusted R } \\
\text { Square }\end{array}$ & \\
\hline 1 & $.898^{a}$ & .806 & .789 & .878 \\
\hline
\end{tabular}

a. Predictors: (Constant), X3, X1, X2

Sumber: Data yang diolah, 2021.

Diketahui pada tabel diatas menunjukkan $\mathrm{R}$ sebesar 0,898 yang berarti bahwa korelasi/hubungan antara Kompetensi Apatratur Desa, Sistem Pengendalian Internal, dan Komitmen Organisasi terhadap Akuntailitas dalam Pengelolaan Dana Desa mempunyai hubungan yang sangat kuat sebesar $89,8 \%$. Dikatakan sangat Kuat karena angka tersebut diatas 0,5 atau diatas $50 \%$.

Sedangkan nilai $\mathrm{R}$ Square atau nilai koefision determinasi diperoleh sebesar 0,806. Hal tersebut dapat dinterprestasikan bahwa variabel $\mathrm{X}$ memiliki pengaruh kontribusi sebesar $80,6 \%$ terhadap variabel Y. Sedangkan sisanya $(100 \%-80,6 \%=19,4 \%)$ dijabarkan oleh variabel independen lain yang tidak termasuk dalam penelitian ini.

Uji Signifikansi Parameter Individual (Uji t) Uji t pada dasarnya menunjukkan seberapa jauh pengaruh variabel penjelas.independen secara individual dalam menerangkan variasi variabel dependen. Jika $\mathrm{t}$ tabel $<\mathrm{t}$ hitung < maka Ho diterima, artinya tidak ada pengaruh. Jika $t$ hitung < t tabel atau thitung > t tabel maka Ho ditolak, artinya ada pengaruh.

\begin{tabular}{|c|c|c|c|c|c|c|}
\hline & & & $\begin{array}{l}16 \text { Hasil Uji t } \\
\text { oefficients }^{a}\end{array}$ & & & \\
\hline & & Unstandardize & efficients & $\begin{array}{l}\text { Standardized } \\
\text { Coefficients }\end{array}$ & & \\
\hline & & $\mathrm{B}$ & Std. Error & Beta & $\mathrm{T}$ & Sig. \\
\hline 1 & (Constant) & -33.183 & 7.450 & & -4.454 & .000 \\
\hline & X1 (Kompetensi) & .182 & .084 & .162 & 2.154 & .038 \\
\hline & X2 (SPIP) & .212 & .023 & .706 & 9.272 & .000 \\
\hline & X3 (Komitmen) & 1.169 & .250 & .363 & 4.674 & .000 \\
\hline
\end{tabular}

a. Dependent Variable: $Y$

Sumber : Data yang diolah, 2021.

Berikut penjelasan mengenai tabel diatas :

1. Pada Variabel Kompetensi Aparatur Desa menunjukkan nilai $t_{\text {hitung }}$ untuk kompetensi aparatur desa adalah sebesar 2,154dengan nilai $t_{\text {tabel }}$ pada tingkat signifikan $5 \%$ dan derajat bebas df = $\mathrm{n}-\mathrm{k}-1=40-3-1=36$ sebesar 1,688. Nilai $t_{\text {hitung }}>t_{\text {tabel }}$ maka hipotesis diterima. Kemudian dilihat dari nilai signifikansi sebesar 0,03 yang artinya nilai signifikansi variabel kompetensi aparatur desa lebih kecil dari 0,05, maka dapat dinyatakan kompetensi aparatur desa berpengaruh positif dan signifikan antara terhadap akuntabilitas pengelolaan dana desa (Ha diterima dan Ho ditolak).

2. Pada Variabel Sistem Pengendalian Intern Pemerintah menunjukkan, nilai $t_{\text {hitung }}$ adalah sebesar 9,272 dengan nilai $t_{\text {tabel }}$ pada tingkat signifikan $5 \%$ dan derajat bebas $\mathrm{df}=\mathrm{n}-\mathrm{k}-1=40-3-1=36$ sebesar 1,688. Jika dibandingkan antara Nilai $t_{\text {hitung }} t_{\text {tabelmaka nilai }} t_{\text {hitung }}>t_{\text {tabel }}$ maka artinya hipotesis diterima. Kemudian dilihat dari nilai signifikan sebesar sebesar 0,00 yang artinya nilai signifikansi variabel Sistem 
Pengendalian Intern Pemerintah lebih kecil dari 0,05, maka dapat dinyatakan Sistem Pengendalian Intern Pemerintah berpengaruh positif dan signifikan antara terhadap akuntabilitas pengelolaan dana desa (Ha diterima dan Ho ditolak).

3. Pada Variabel Komitmen Organisasi nilai

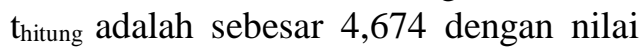
$t_{\text {tabel }}$ pada tingkat signifikan $5 \%$ dan derajat bebas $\mathrm{df}=\mathrm{n}-\mathrm{k}-1=40-3-1=36$ sebesar 1,688. Jika dibandingkan antara Nilai $t_{\text {hitung }} t_{\text {tabelmaka nilai }} t_{\text {hitung }}>t_{\text {tabel }}$ maka artinya hipotesis diterima. Kemudian dilihat dari nilai signifikan sebesar sebesar 0,00 yang artinya nilai signifikansi variabel Komitmen Organisasi lebih kecil dari 0,05, maka dapat dinyatakan Komitmen Organisasi berpengaruh positif dan signifikan antara terhadap akuntabilitas pengelolaan dana desa (Ha diterima dan Ho ditolak).

\section{Uji Signifikan Simultan (Uji F)}

Uji statistik $F$ bertujuan untuk mengetahui pengaruh variabel independen secara bersama-sama terhadap variabel dependen. Nilai Ftabel dapat dilihat pada tabel statistik dengan tinngkat signifikansi 0,05 dengan df $1(\mathrm{k}-1)$ atau 3 $-1=2$, dan df $2(n-k)$ atau $40-3=37$ sebesar 2 , 859.

Tabel 7 Hasil Uji Simultan (Uji F)

\begin{tabular}{llr|r|r|r|r}
\multicolumn{1}{c}{} & \multicolumn{2}{c}{ ANOVA $^{\mathrm{a}}$} & & & \\
Model & Sum of Squares & Df & Mean Square & F & Sig. \\
\hline 1 & Regression & 115.026 & 3 & 38.342 & 49.743 & $.000^{\mathrm{b}}$ \\
\cline { 2 - 7 } & Residual & 27.749 & 36 & .771 & & \\
\cline { 2 - 7 } & Total & 142.775 & 39 & & & \\
\hline
\end{tabular}

\footnotetext{
a. Dependent Variable: $Y$

b. Predictors: (Constant), X3, X1, X2
}

Sumber : Data yang diolah, 2021

Berdasarkan hasil uji signifikansi simultan (uji statistik F) pada tabel 4.16, menunjukkan nilai $F$ perhitungan sebesar 49.743 dengan tingkat signifikansi $0,000 . \mathrm{F}_{\text {hitung }}$ menunjukkan angka yang lebih besar dari pada $\mathrm{F}_{\text {tabel }}$ atau 49.743 > 2.859dan nilai signifikansi jauh lebih kecil dibandingkan dengan 0,05 sehingga dapat dinyatakan bahwa kompetensi aparatur desa, sistem pengendalian internal dan komitmen organisasi secara bersama-sama berpengaruh positif dan signifikan terhadap akuntabilitas pengelolaan dana desa.

\section{PEMBAHASAN}

\section{Pengaruh Kompetensi Aparatur Desa terhadap Akuntabilitas Pengelolaan Dana Desadi Kecamatan Muara Enim Kabupaten Muara Enim}

\footnotetext{
Berdasarkan uji hiposisi yang dilakukan oleh peneliti nilai thitung untuk kompetensi aparatur desa senilai 2,154jika dibandingkan dengan nilai $t_{\text {tabel }}$ adalah 1,688 , maka nilai $t_{\text {hitung }}>$ nilai $t_{\text {tabel }}$, sehingga $\mathrm{Ha}$ diterima atau Ho ditolak. Sehingga dapat ditarik kesimpulan bahwa kompetensi aparatur
}

desa berpengaruh positif terhadap Akuntabilitas dalam Pengelolaan Dana Desa di desa-desa yang terdapat di Kecamatan Muara Enim Kabupaten Muara Enim. Di lihat dari nilai Signifikan menunjukkan bahwa nilai Signifikan kompetensi aparatur desa adalah sebesar 0.03 yaitu lebih kecil dari 0.05 artinya kompetensi aparatur desa berpengaruh signifikan terhadap Akuntabilitas dalam Pengelolaan Dana Desa di desa-desa yang terdapat di Kecamatan Muara Enim Kabupaten Muara Enim.

Hasil tersebut sejalan atau searah dengan penelitian terdahulu yang dilakukan oleh Ni Putu Dessy Eka Ariani, dkk (2020) dimana hasil dari penelitian menunjukkan bahwa kompetensi aparatur desa berpengaruh positif dan signifikan terhadap Akuntabilitas dalam Pengelolaan Dana Desa, yang berarti bahwa semakin tingginya tingkat kompetensi yang dimiliki oleh aparatur desa maka akan meningkatkan akuntabilitas dalam pengelolaan dana desa. Aparatur desa harus memiliki kompetensi maupun kemampuan berupa pengetahuan, keterampilan dan sikap serta etika yang baik dalam melaksanakan 
semua fungsi pokok dan tugas dalam pengelolaan dana desa. Berbagai hal bisa dilakukan oleh pemerintah desa untuk meningkatkan kompetensi yang dimiliki oleh aparatur desa, dengan mengikut sertakan para aparatur desa dalam berbagai pelatihan kompetensi dan pelatihan-pelatihan lainnya yang bisa meningkatkan kemampuan dan kompetensi apartur desa tersebut.

\section{Pengaruh Sistem Pengendalian Intern Pemerintah terhadap Akuntabilitas Pengelolaan Dana Desa di Kecamatan Muara Enim Kabupaten Muara Enim}

Berdasarkan uji hiposisi yang dilakukan oleh peneliti nilai $t_{\text {hitung }}$ untuk Sistem Pengendalian Intern Pemerintah senilai 9,272 jika dibandingkan dengan nilai $t_{\text {tabel }}$ adalah 1,688, maka nilai $t_{\text {hitung }}>$ nilai $t_{\text {tabel, }}$, sehingga Ha diterima atau Ho ditolak. Sehingga dapat ditarik kesimpulan bahwa Sistem Pengendalian Intern Pemerintah berpengaruh positif terhadap Akuntabilitas dalam Pengelolaan Dana Desa di desa-desa yang terdapat di Kecamatan Muara Enim Kabupaten Muara Enim. Di lihat dari nilai Signifikan menunjukkan bahwa nilai Signifikan ko Sistem Pengendalian Intern Pemerintah adalah sebesar 0.00 yaitu lebih kecil dari 0.05 artinya Sistem Pengendalian Intern Pemerintah berpengaruh signifikan terhadap Akuntabilitas dalam Pengelolaan Dana Desa di desa-desa yang terdapat di Kecamatan Muara Enim Kabupaten Muara Enim. Hasil yang didapat pada penelitian ini searah dengan penelitian yang dilakukan oleh Nur Ida Yesinia, dkk (2018) yang menyatakan bahwa Sistem Pengendalian Intern Pemerintah berpengaruh positif dan signifikan terhadap Akuntabilitas dalam Pengelolaan Dana Desa.

$$
\text { Sistem Pengendalian Intern }
$$

Pemerintah berpengaruh terhadap Akuntabilitas dalam Pengelolaan Dana Desa karena Sistem Pengendalian Intern Pemerintah dapat meminimalisir kesalahan atau kecurangan yang dilakukan dalam pengelolaan dana desa, dengan adanya Sistem Pengendalian Internal data akuntansi akan dilakukan pengecekan sehingga hasil data akuntansi akan terjamin ketelitian dan keandalannya. Serta dalam pengelolaan dana desa akan sesuai dengan kebijakan pemerintah desa yang disusun berdasarkan peraturan perundang-undangan yang berlaku. Serta jelasnya pemisahan tugas dan fungsi pokok dalam hal pengelolaan dana desa, tidak adanya rangkap jabatan sehingga dapat meminimalisir adanya kesalahan dan berbagai macam kecurangan yang bisa dilakukan.

\section{Pengaruh Komitmen Organisasi Pemerintah terhadap Akuntabilitas Pengelolaan Dana Desa di Kecamatan Muara Enim Kabupaten Muara Enim}

Berdasarkan uji hiposisi yang dilakukan oleh peneliti nilai $t_{\text {hitung }}$ untuk Komitmen Organisasi senilai 4,674 jika dibandingkan dengan nilai tabel adalah 1,688, maka nilai $t_{\text {hitung }}>$ nilai $t_{\text {tabel, }}$, sehingga $\mathrm{Ha}$ diterima atau Ho ditolak. Sehingga dapat ditarik kesimpulan bahwa Komitmen Organisasi berpengaruh positif terhadap Akuntabilitas dalam Pengelolaan Dana Desa di desa-desa yang terdapat di Kecamatan Muara Enim Kabupaten Muara Enim. Di lihat dari nilai Signifikan menunjukkan bahwa nilai Signifikan Komitmen Organisasi adalah sebesar 0.00 yaitu lebih kecil dari 0.05 artinya Komitmen Organisasi berpengaruh signifikan terhadap Akuntabilitas dalam Pengelolaan Dana Desa di desa-desa yang terdapat di Kecamatan Muara Enim Kabupaten Muara Enim.

Hasil yang didapat pada penelitian ini searah dengan penelitian yang dilakukan oleh Siti Sarah,dkk (2020) yang menyatakan bahwa Komitmen Organisasi berpengaruh positif dan signifikan terhadap Akuntabilitas dalam Pengelolaan Dana Desa, yang berarti bahwa dengan semakin di tingkatkannya tingkat Komitmen Organisasi maka akan meningkatkan tingkat Akuntabilitas dalam Pengelolaan Dana Desa. Adanya komitmen yang tinggi akan mempertangungjawabkan segala kegiatan yang dilakukannya dalam organisasi untuk mewujudkan pelayanan kepada publik agar menjadi lebih baik (Siti Sarah,dkk 2020) hal ini sejalan dengan teori stewardship dimana aparatur pengelola dana desa harus memiliki komitmen yang tinggi terhadap organisasi untuk memenuhi kewajibannya dalam memberikan pelayanan kepada masyarakat. 


\section{Pengaruh Kompetensi Aparatur Desa, Sistem Pengendalian Intern Pemerintah dan Komitmen

Organisasi terhadap Akuntabilitas
Pengelolaan Dana Desa di
Kecamatan Muara Enim Kabupaten
Muara Enim

Berdasarkan uji hiposisi yang Akuntabilitas dalam Pengelolaan Dana Desa adalah sebesar 49.743 jika dibandingkan dengan nilai $F_{\text {tabel }}$ adalah 2.859. Maka $F_{\text {hitung }}$ yang diperoleh lebih besar dari nilai $\mathrm{F}_{\text {tabel, }}$ kemudian untuk nilai signifikan 0.00 lebih kecil daripada 0.05 sehingga dapat ditarik kesimpulan bahwa variabel independen Kompetensi Aparatur Desa, Sistem Pengendalian Intern Pemerintah, dan Komitmen Organisasi berpengaruh secara bersama-sama berpengaruh positif dan signifikan terhadap Akuntabilitas dalam Pengelolaan Dana Desa. Berdasarkan hasil analisis kekuatan hubungan secara simultan atau analisis untuk mengetahui seberapa besar variabel bebas menjelaskan variabel terikat, dapat diketahui bahwa nilai koefisien determinasi R2 sebesar 0,806 atau 80,6\% sedangkan sisanya sebesar $100 \%-80,6 \%=$ $19,4 \%$ dipengaruhi oleh variabel lain yang tidak peneliti gunakan pada penelitian ini.

Nilai sebesar 80,6\% menunjukkan bahwa variabel akuntabilitas pengelolaan dana desa dipengaruhi oleh kompetensi aparatur desa, sistem pengendalian internal pemerintah dan komitmen organisasi sebesar $80,6 \%$ pada seluruh desa pada Kecamatan Muara Enim Kabupaten Muara Enim. Hasil penelitian ini sejalan dengan penelitian terdahulu yang dilakukan oleh Siti Sarah, dkk (2020) menyatakan bahwa Kompetensi Aparatur, Komitmen Organisasi, Pemanfaatan Teknologi Informasi, Partisipasi Masyarakat, dan Sistem Pengendalian Intern Pemerintah berpengaruh positif dan signifikan terhadap Akuntabilitas Dalam Pengelolaan Keuangan Desa dengan hal ini dapat dikatakan bahwa dengan ditingkatkannya Kompetensi Aparatur Desa, Sistem Pengendalian Intern Pemerintah, dan Komitmen Organisasi secara bersama-sama dapat meningkatkan Akuntabilitas dalam pengelolaan dana desa secara positif dan signifikan.

\section{KESIMPULAN DAN SARAN}

Dari hasil analisis dan pembahasan, dapat disimpulkan bahwa secara parsialterdapat pengaruh positif dan signifikan pada Kompetensi aparatur desa, Sistem Pengendalian Internal dan Komitmen Organisasi berpengaruh terhadap Akuntabilitas Pengelolaan Dana Desa. Sedangkan secara simultan, terdapat pengaruh positif dan signifikan pada Kompetensi aparatur desa, Sistem Pengendalian Internal dan Komitmen Organisasi berpengaruh terhadap Akuntabilitas Pengelolaan Dana Desapada Kecamatan Muara Enim Kabupaten Muara Enim secara Simultan.

Bagi aparatur desa diharapkan untuk selalu meningkatkan kompetensi dalam pengelolaan keuangan desa yang baik dan benar dengan cara mengikuti pelatihan, sosialiasi mengenai pengelolaan dana desa sesuai dengan peraturan perundang-undangan supaya bisa meningkatkan kemampuan dalam mengelola dana desa sehingga dana desa bisa digunakan untuk sebaik-baiknya pembangunan desa dan kesejahteraan masyarakat desadan selalu meningkatkan Sistem Pengendalian Internal dalam pengelolaan dana desa sehingga akan lebih membantu dalam pengawasan terhadap ketaatan pengelolaan dan pelaporan keuangan desa serta diharapkan untuk selalu meningkatkan komitmen terhadap organisasi sehingga rasa memiliki organisasi bisa mendukung dalam hal mencegah penyelewengan terhadap dana desa demi kepentingan pribadi sendiri.

\section{DAFTAR PUSTAKA}

Arif Widyatama, Lola Novita dan Diarespati (2017) "Pengaruh Kompetensi dan Sistem Pengendalian Internal Terhadap Akuntabilitas Pemerintah Desa dalam Mengelola Alokasi Dana Desa (ADD)" Jurnal Riset AkuntansiVol. 02, No. 02 (2017): 1-20.

Dekeng Setyo Budiarto, Agesti Dwi Setyaningrum dan Ratna Purnama Sari (2020) "Akuntabilitas Pengelolaan Dana Desa dan Faktor Anteseden yang mempengaruhinya" Jurnal Ekonomi, Manajemen Dan Akuntansi Vol.23.No.2 Agustus (2020).

Fifit Nur Walyati dan Farida (2020) "Pengaruh Partisipasi Masyarakat, Kompetensi Dan Sistem Pengendalian Internal Terhadap Akuntabilitas Pengelolaan Dana Desa (Studi Empiris Pada Desa 
Se-Kecamatan Muntilan) Journal of Economic and Business.

Ghozali, Imam.2018. Aplikasi Analisis Multivriate dengan Program IBM SPSS 25. Badan Penerbit Universitas Diponegoro: Semarang.

I Putu Juliantoa, dan Gusti Ayu Ketut Rencana Sari Dewi (2019) "Pengaruh Partisipasi Masyarakat, Penggunaan Sistem Keuangan Desa, Kompetensi Pendamping Desa, Komitmen Pemerintah Daerah Terhadap Keberhasilan Pengelolaan Dana Desa" Jurnal Riset AkuntansiVol. 4, No. 1, Juni (2019): 24-42

Kartika Restu Aprilya dan Astri Fitria (2017) "Pengaruh Kompetensi Aparatur Pengelola Dana Desa, Komitmen Organisasi, Transparansi, dan Partisipasi Masyarakat Terhadap Akuntabilitas Pengelolaan Dana Desa di Kabupaten Gresik." Jurnal Riset Akuntansie-ISSN: 2460-0585.

Mardiasmo. 2018. Akuntansi Sektor Publik.

Yogyakarta: ANDI.

Mulyadi.(2017). Sistem Akuntansi (Edisi

Empat). Salemba Empat.

Muhammad Ismail, Ari Kuncara Widagdo, dan Agus Widodo (2016) " Sistem Akuntansi Pengelolaan Desa" Jurnal Ekonomi dan Bisnis Vol.19 No.2 Agustus (2016).

Ni Komang Ayu Julia Praba Dewi dan Gayatri (2019) "Faktor-Faktor Yang

Berpengaruh Pada Akuntabilitas Pengelolaan Dana Desa" E-Jurnal Akuntansi Vol.26.2.Februari (2019): 1269-1298.

Ni Putu Dessy Eka Aryani, Dr. Desak Nym Sri Werastuti dan I Made Pradana Adiputra (2020) "Pengaruh Kompetensi Aparatur Pemerintah Desa, Efektivitas Kinerja Pendamping Lokal Desa dan Keterlibatan Masyarakat Terhadap Pengoptimalan Pengelolaan Dana Desa" Journal of Accounting Vol.11 No. 2 Tahun 2020 eISSN: $2614-1930$.

Nur Ida Yesinia, Norita Citra Yuliarti, dan Dania Puspitasari (2018) “Analisis Faktor yang Mempengaruhi Akuntabilitas Pengelolaan Alokasi Dana Desa" Jurnal Riset Akuntansi Vol.10, No. 01.( 2018): 105-11.
Peraturan Menteri Dalam Negeri (Permendagri) No. 20 Tahun 2018 Tentang pengelolaan keuangan desa. .No. 108 Tahun 2017 Tentang Kompetensi Pemerintahan.

Peraturan Menteri Ketenagakerjaan (Permenaker) No. 1 Tahun 2017

Tentang Struktur dan Skala Upah.

Peraturan Pemerintah (PP) No.71 Tahun 2010 Tentang Standar Akuntansi Pemerintah. . (PP)Nomor 8 Tahun 2016 Tentang Dana Desa.

(PP) No. 23 Tahun 2004 Tentang Badan Nasional Sertifikasi Profesi. . (PP) No. 60 Tahun 2008 tentang Sistem Pengendalian Intern Pemerintah.

Peraturan Menteri Dalam Negeri Nomor 84 Tahun 2016 tentang Susunan Organisasi Dan Tata Kerja Pemerintah Desa.

Peraturan Menteri Keuangan Nomor 205 Tahun 2019 tentang Pengelolaan Dana Desa.

Sahmin Noholo dan Mohammad Zubair Hippy (2021) "Pengaruh Kompetensi SDM, Prinsip Akuntabilitas Terhadap Pengelolaan Keuangan Desa Di Kecamatan Suwawa Selatan".Journal of Accounting.Vol. 2, No.1 Februari 2021.

Sarifudin Mada, Lintje Kalangi, dan Hendrik Gamaliel (2019) "Pengaruh Kompetensi Aparat Pengelola Dana Desa, Komitmen Organisasi Pemerintah Desa, dan Partisipasi Masyarakat Terhadap Akuntabilitas Pengelolaan Dana Desa di Kabupaten Gorontalo."

Siti Sarah, Taufeni Taufik, dan Devi Safitri (2020) “ Pengaruh Kompetensi Aparatur, Komitmen Organisasi, Pemanfaatan Teknologi Informasi, Partisipasi Masyarakat, dan Sistem Pengendalian Internal terhadap Akuntabilitas Pengelolaan Dana Desa di Kabupaten Indragiri Hulu. Journal of Accounting.Vol. 4 No. 4, Desember 2020.

Siti Nurhasanah. 2016. Aplikasi dengan Ms. Excel dan SPSS.Jakarta Selatan : Salemba Empat.

Sugiyono. 2016. Metode Penelitian Pendidikan Pendekatan Kuantitatif, Kualitatif, dan $R \& D$. Bandung: Eidos. 
JEMBATAN (Jurnal Ekonomi, Manajemen, Bisnis, Auditing, dan Akuntansi) Vol.6, No.1, Juni 2021 : $26-38$

Sugiyono. 2019. Metode Penelitian Kuantitatif, Kualitatif dan $R \& D$. Bandung: Alfabeta.

Undang-Undang Nomor 6 Tahun 2014 Tentang Desa.
Nomor 13 Tahun 2003 Tentang Ketenagakerjaan

Yusuf, Ria Mardiana dan Darman Syarif (2017) Komitmen Organisasi. Makassar : Nas Media Pustaka. 